\title{
'n Kruiskulturele ondersoek na eensaamheid onder studente van die Universiteit van die Vrystaat
}

\author{
A le Roux, D.Phil., Departement Sielkunde, Universiteit van die Vrystaat
}

\section{Opsomming}

Baie jongmense voel vandag eensaam en hulpeloos en dat die lewe geen betekenis het nie. Die bestaande literatuur toon verder dat hierdie verskynsel besig is om katastrofiese afmetings in veral geïndustrialiseerde Westerse lande aan te neem. Heelwat kruiskulturele studies is al op ander vastelande tussen verskillende bevolkingsgroepe uitgevoer ten einde vas te stel wat die oorsake vir hierdie verskynsel is en of kultuur moontlik ' $n$ belangrike rol in die ontwikkeling van hierdie verskynsel te speel het. Wat hierdie tipe navorsing betref, skiet Suid-Afrika steeds ver tekort en sal ernstige pogings aangewend moet word om te bepaal of eensaamheid ook hier sulke ernstige afmetings aanneem en of jongmense van sekere bevolkingsgroepe meer kwesbaar as andere is, omdat dit ingrypende gevolge vir hul gesondheid inhou. Suid-Afrika met sy ryke bevolkingsverskeidenheid bied besondere geleenthede en uitdagings om konstrukte soos eensaamheid te kan ondersoek en sodoende ' $n$ belangrike bydrae tot die ontrafeling van hierdie multifasettige konstruk te lewer. Die doel van hierdie ondersoek was derhalwe om vas te stel of studente van verskillende kultuurgroepe aan die Universiteit van die Vrystaat van mekaar verskil sover dit hul ervaring van eensaamheid betref. Eensaamheidsvraelyste is onder studente van die universiteit uitgedeel en 270 respondente, waarvan 122 wit en 148 swart was, het aan die ondersoek deelgeneem. ' $n$ Faktoriale variansieontleding is op die data uitgevoer, met eensaamheid as afhanklike veranderlike en kultuur, geslag en ouderdom as onafhanklike veranderlikes. Die resultate toon eerstens dat kultuur ' $n$ baie belangrike veranderlike by die bestudering van eensaamheid is. Swart studente blyk beduidend meer eensaam as wit studente te wees, terwyl geen geslags- of ouderdomsverskille tussen die twee groepe gevind kon word nie.

\section{Abstract}

Many young people today are lonely and hopeless, and feel that life has no meaning. The existing literature indicates that this phenomenon is taking on near-epidemic proportions in industrialised Western countries. A considerable amount of cross-cultural investigations have already been conducted overseas between different population groups, in order to determine what the causes of this phenomenon are and whether culture plays an important role in the development of loneliness. As far as this type of research is concerned South Africa is currently far behind the rest of the world. Serious efforts shall have to be made to determine whether loneliness is taking on the same proportions locally and if certain population groups are more vulnerable than others, because it could have far-reaching consequences on their physical as well as psychological health. South Africa has a rich population variety which could enable researchers to investigate emotional constructs like loneliness that could contribute to the unravelling of this multifaceted phenomenon. The purpose of this investigation was therefore to determine whether students from different cultural backgrounds at the University of the Free State differ from each other, as far as their experience of loneliness is concerned. Questionnaires were distributed among students and 270 respondents, of which 122 were white and 148 black, took part in this study. A factorial analysis of variance was applied on the data, with loneliness as dependent variable, and cultural background, gender and age as independent variables. The results firstly show that cultural background is a very important variable as far as loneliness is concerned. Black students are significantly more lonely than white students while no gender and age differences between the groups were found.

\section{INLEIDING}

Eensaamheid is besig om katastrofiese afmetings in verskeie samelewings aan te neem. Om eensaam te wees of te voel, moet geensins met alleenheid verwar word nie. Alleenheid suggereer om deur tyd en ruimte van iets of iemand geskei te wees. Sodanige persone hoef ook nie noodwendig ongelukkig oor hul alleenheid te voel nie. So byvoorbeeld kan ' $n$ persoon alleen op ' $n$ eiland of afgesonderde gebied navorsing oor een of ander dier- of plantspesie doen en baie gelukkig wees. Of iemand kan alleen in ' $n$ kamer sit en lees en dit baie geniet. Aan die anderkant is mense wat 
eensaam is of voel, altyd ongelukkig. Hulle ervaar dikwels dat hul behoeftes nie bevredig word nie, of dat hulle nie oor ' $n$ netwerk van vriende beskik om in hierdie behoeftes te voorsien nie. Hulle glo ook dat niemand vir hulle omgee of hulle lief het nie.

Niemand is immuun teen eensaamheid nie, maar dit is egter problematies dat verskeie ondersoeke reeds aangetoon het dat dit veral jongmense is wat die grootste slagoffers van hierdie verskynsel is (Le Roux, 2001:85; McWhirter, 1990:59; Medora \& Woodward, 1986:398; Parlee, 1979:47; Rokach \& Brock, 1997:5). Volgens Cruz (1983:37) voel baie jongmense eensaam en dat die lewe geen betekenis het nie. In ' $n$ brief aan hom skryf ' $n$ jong adolessent die volgende (Cruz, 1983: 37):

Liewe Nicky, Ek is ' $n$ meisie van sestien jaar. Alles is vir my die afgelope tyd so neerdrukkend, en ek voel soos ' $n$ wrak.............. Ek is baie eensaam en verward. Ek wil so graag normaal wees, maar dit is onmoontlik................Ek soek gedurig na antwoorde, maar ek kry niks nie............Ek stry teen bedruktheid en eensaamheid. Ek weet nooit wie ek werklik kan vertrou nie............. Nicky, sal jy nie asseblief, asseblief vir my bid nie en my op die een of ander manier probeer help nie?

Hierdie is een van die menigte probleme waarmee sielkundiges en medici daagliks gekonfronteer word. Te midde van hoë egskeidingsyfers, politieke stelsels wat misluk, leiers wat faal, hoë vlakke van kindermishandeling, seksuele molestering, verkragting, bloedskande, misdaad, moord, en baie ander probleme, word meer en meer jong mense eensaam. Dit hou ernstige gevolge vir hul fisiese en psigologiese gesondheid in (Groenewald, 1998:47). Volgens hierdie navorser is eensaamheid ' $n$ groot onreg wat verdra moet word, omdat ' $n$ persoon se selfbeeld en selfwaarde baie negatief daardeur beïnvloed word. Sy vervolg dat die eensame persoon se interpersoonlike lewe ook leeg en hol is. Moeder Theresa het in hierdie verband opgemerk: "What an extreme poverty loneliness, shyness, the feeling of thinking that no one wants you and of feeling despised, and lacking everything, is" (cited in Gonzalez, 1997:92).

Die bestaande literatuur oor eensaamheid toon dat hierdie verskynsel besig is om epidemiese proporsies in geïndustrialiseerde Westerse lande aan te neem. Volgens Groenewald (1998:2) moet die hoofoorsaak hiervoor in hierdie samelewings se klem op individualisme geplaas word. Verder is dit ook te wyte aan die feit dat belangrike ondersteuningstelsels, soos die uitgebreide gesin, geleidelik aan die verdwyn is. Die gevolg hiervan is dat basiese behoeftes, soos interpersoonlike intimiteit en emosionele sekuriteit nie langer bevredig word nie. Verder blyk ook dat eensaamheid geen onderskeid tref tussen ras, geslag of ouderdom nie. Enigeen kan een of ander tyd 'n slagoffer van eensaamheid word (Ferns, 1991:55; Peplau \& Perlman, 1982:5; Rokach, 1988:7).

Volgens die literatuur word hierdie fenomeen ook geassosieer met afwykings soos depressie, eetversteurings, selfmoord, vyandigheid, jeugmisdaad, alkoholisme, homoseksualiteit, sosiale onttrekking, swak skoolprestasie, gebrek aan beheer, pessimisme en verwerping (Andersson, 1993:585; Barretta, Dantzler, \& Kayson, 1995:828; Demir \& Tarhan, 2001:115; Jones \& Moore, 1987:148; Kastenbaum, 1979:15; Le Roux, 1996:5; McWhirter, 1990:60; Newman \& Newman, 1995:15; Nurmi, Toivonen, Salmela-Aro \& Eronen, 1997:771; Rokach, 2001:283). Lynch (1977) is verder van mening dat eensaamheid ook die liggaam affekteer, wat tot 'n groter predisposisie vir sekere siektes kan lei. Fisiese simptome soos slaap- en eetversteurings, asook hoofpyne, word ook gerapporteer (Peplau \& Perlman, 1982:11), terwyl eensame persone ook gevoelens van chroniese moegheid, pyn en spanning ervaar (Berg, Mellström, Persson \& Svanberg, 1981:345; Gerstein \& Tesser, 1987:349; Weiss, 1973; Williams, 1987:185). Lynch (1977) is ook van mening dat chroniese eensaamheid tot ernstige kardiovaskulêre siektes en selfs die dood aanleiding kan gee.

Al bogenoemde nagatiewe gevolge wat eensaamheid op die fisiese en psigiese gesondheid van adolessente kan hê, maak dit dringend noodsaaklik dat verdere navorsing omtrent die voorkoms van hierdie verskynsel onder jong mense van alle kultuurgroepe uitgevoer sal word, ten einde die verreikendheid van hierdie fenomeen te probeer bepaal (Le Roux, 2001:85; Groenewald, 1998:20; Ginter, AbdelKhalek \& Scalise, 1995:54). In vergelyking met oorsese navorsing skiet kruis-kulturele Suid-Afrikaanse ondersoeke ver tekort. Slegs 'n paar studies, naamlik dié van Groenewald (1998); Le Roux en Connors (2001); Mullett (2002) en Pretorius (1993) is reeds binne Suid-Afrikaanse konteks uitgevoer. Dit lê ' $n$ groot leemte bloot, wat die navorser genoodsaak het om verdere ondersoek na die komplekse aard van hierdie verskynsel in te stel.

In vorige artikels deur Le Roux $(2001: 84 ; 1998: 176)$ is breedvoerige uiteensettings van die verskeidenheid definisies in die literatuur oor eensaamheid reeds verskaf, wat herhaling hier onnodig maak. Ter wille van die leser word enkele definisies oor die aard van hierdie verskynsel egter aangehaal:

Demir en Tarhan (2001:113) omskryf eensaamheid op die volgende wyse:

Eensaamheid word gedefinieer as 'n onaangename ervaring wat voorkom wanneer ' $n$ persoon se netwerk van sosiale verhoudings aansienlik afwykend ten opsigte van kwaliteit en/of kwantiteit is.

Volgens McGraw (1992:319) kan dit as volg gedefinieer word:

..loneliness can be defined as the lack of intimacy and meaning in personal or personified relationships. Loneliness is not, just any lack of intimacy or meaning, but of that kind of intimacy which is meaningful and that form of meaning which is intimate.

Verskeie faktore is reeds as moontlike oorsake vir eensaamheid geïdentifiseer. In 'n multi-dimensionele model vir eensaamheid deur Rokach en Brock (1997:2) is emosionele behoefte as die hoofoorsaak aangewys. Heelwat ander navorsers en skrywers beskou ook 
emosionele toestande as ' $n$ hoofdeterminant van eensaamheid (De Beer, 1992:5; Ferns, 1991:55; Peplau \& Perlman, 1982:13; Scholtz, 1995:7; Weiss, 1973). Emosionele eensaamheid ontstaan uit óf die afwesigheid en/of die verbreking van intieme emosionele bande met sommige of al die individu se verhoudinge, óf deur veranderings binne hierdie verhoudings wat deur omstandighede veroorsaak is. Persone wat emosioneel geisoleerd is, het ' $\mathrm{n}$ gebrek aan ' $n$ intieme verbondenheidsfiguur na wie hulle in tye van krisis kan gaan. Dit kan tot skeidingsangs aanleiding gee (Weiss, 1989:79). Hierdie individue toon ook 'n gebrek aan verhọudings met genoegsame intimiteit om hul diepste behoeftes en verlangens mee te deel. Die verlatenheid en verwerping wat deur sulke persone ervaar word, lei tot gevoelens van leegheid en ' $n$ intense verlange na liefde en aanvaarding deur ander (Cruz, 1983:14). Verskeie hoë risikogroepe vir eensaamheid wat op die voorgenoemde gebaseer is, word vervolgens aangetoon. Dit sluit die volgende in:

- $\quad$ Slagoffers van traumatiese kinderervarings. Dit sluit die egskeiding of dood van ouers, asook mishandeling en/of negatiewe gesinsinvloede, in;

- $\quad$ Sosiale uitgeworpenes, byvoorbeeld gestremdes;

- Mense in die lae sosio-ekonomiese klas. In die moderne samelewing het mense tyd en geld vir die onthaal van vriende, asook die bou van verhoudings, nodig;

- $\quad$ Egskeiding. Dit lei tot emosionele trauma en " $\mathrm{n}$ verlies aan sosiale verhoudings;

- Disfunksionele huwelike. Dit sluit huwelikskonflik en onbevredigde behoeftes in (De Beer, 1992:35; Gaev, 1976; Odendal, 1985:15; Peplau \& Perlman, 1982:12; Rubenstein \& Shaver, 1982:215; Scholtz, 1995:31; Taylor, Peplau \& Sears, 2000:345);

- Persoonlikheidsfaktore. Dit sluit suspisie, selfbewustheid, skaamheid, skuldgevoelens, lae selfagting, asook ' $n$ eksterne lokus van kontrole in (Cheek \& Busch, 1981:574; Diamant \& Windholz, 1981:518; Ferns, 1991:36; Hojat, 1982:139; Janse van Rensburg, 1991:55, Taylor et al., 2000:345). Individue wat ' $n$ gebrek aan selfvertroue het, sal nie oor die nodige vryheid beskik om hul gevoelens uit te druk nie (Hansson \& Jones, 1981:104). Hierdie individue voel nutteloos en is ontevrede met hulleself (Hojat, 1982:139; Peplau \& Perlman, 1982:12).

Eensame mense is ook meer geïrriteerd (Rubenstein \& Shaver, 1982:215) en is geneig om ander individue negatief te beoordeel (Jones, Sansone \& Helm, 1983:439). Volgens Cutrona (1982:295); Diamant en Windholz (1981:518) en Moore (1972:2287B) ervaar onderdanige mense ook meer eensaamheid.

Afgesien van die bogenoemde is baie filosowe en teoloë daarvan oortuig dat geloof ook ' $\mathrm{n}$ belangrike determinant vir eensaamheid is (MacArthur, 1995:50; McGraw, 1992:319; Couwenberg, 1959:14; Graham, 1993:29). 'n Aantal empiriese studies het ook reeds ' $n$ beduidende omgekeerde verband tussen geloof en eensaamheid aangetoon (Allport \& Ross, 1967; Le Roux, 1998:179; 2002:228). In die laasgenoemde studie is die Christelike geloof as "n hoogs beduidende voorspeller vir eensaamheid uitgewys. Dit beteken dat hoe sterker ' $n$ persoon se geloof in Jesus Christus is, hoe minder sal hy/sy geneig wees om eensaam te wees, en omgekeerd. Ander veranderlikes wat met geloof in Jesus Christus geassosieer word en wat ook tot die voorspelling van eensaamheid bygedra het, is die frekwensie vir gebed, kerkbywoning, asook wedergeboorte deur die Heilige Gees.

Soos reeds genoem, is kruis-kulturele ondersoeke oor eensaamheid in Suid-Afrika tot enkele studies beperk, terwyl daar reeds talle ondersoeke in oorsese lande uitgevoer is. So byvoorbeeld het Shumaker, Shea, Monfries en GrothMarnat (1993:67) 'n ondersoek tussen 121 Japanese en 139 Australiese studente uitgevoer en bevind dat die Japanese studente beduidend meer eensaam as die Australiese studente was. Verder was hulle algemene lewenstevredenheid ook laer as die van die Australiërs. Volgens die navorsers moet die redes hiervoor by die Japanese sosiale struktuur wat meer klem op interafhanklikheid in stede van outonomie plaas, gesoek word. As gevolg hiervan het hulle ' $n$ groter predisposisie vir eensaamheid, omdat hulle - anders as die Australiese groep - nie die nodige vaardighede ontwikkel het om die verlies aan sosiale ondersteuningsnetwerke te hanteer nie.

Ginter, Glauser en Richmond (1994:877) het 'n ondersoek tussen twee verskillende Suidsee kulture uitgevoer ten einde vas te stel of daar verskille ten opsigte van die verband tussen eensaamheid, angs en sosiale ondersteuning is. Wat die eerste groep betref, is " $n$ direkte positiewe verband tussen eensaamheid en angs gevind, terwyl "n verlies aan vriende ook met die ervaring van eensaamheid gekorreleer het. Die resultate het ook getoon dat wat die oorsaaklike rol vir sosiale ondersteuning betref, die tweede groep se gebrek aan vriende en gesinsondersteuning met hul eensaamheid geassosieer kon word (Ginter et al., 1994:877). In 'n ander ondersoek deur Medora, Woodward en Larson (1987:399) is kulturele verskille tussen Amerikaanse en Indiese adolessente ten opsigte van eensaamheid gevind. Die Amerikaanse vroulike adolessente was eensamer as die Indiese vroulike adolessente, terwyl geen verskille tussen die twee groepe manlike respondente gevind is nie. Die navorsers het verklaar dat die vroulike Amerikaanse adolessente meer in kontak met hul gevoelens as die Indiese groep was en dat hul sosialiseringsproses hulle onderrig het om hul emosies te erken en uit te druk. Die Amerikaanse adolessente was ook meer kwesbaar vir eensaamheid in " $n$ individualistiese Westerse kultuur in vergelyking met die Indiese adolessente wat uit ' $n$ meer gesinsgeoriënteerde kultuur afkomstig is.

In ' $\mathrm{n}$ ander studie tussen 170 wit Amerikaanse eerstejaar studente en 34 swart studente het Sundberg (1988:301) gevind dat die wit studente beduidend meer eensaam as die swart studente was. 'n Groep van 417 Egiptiese jong volwassenes is in ' $n$ ander studie deur Ginter et al. (1995:55) gebruik ten einde die affektiewe dimense van eensaamheid te ondersoek. Net soos met die Amerikaanse respondente (Scalise,Ginter \& Gerstein, 1984:528) het geblyk dat die 
Egiptiese studente tydens periodes van eensaamheid ' $n$ tipe interpersoonlike eensaamheid ervaar, wat beteken het dat hulle ' $n$ verwydering van of die interpersoonlike of sosiale omgewings ervaar het. Die intrapersoonlike affektiewe dimensie van eensaamheid het aangetoon dat die Egiptiese respondente gevoelens van depressie, wanhoop, emosionele afmatting, emosionele pyn en vrees ervaar het, teenoor gevoelens van agitasie en verbittering van die Amerikaanse groep. Volgens die navorsers moet die verskille in die affektiewe dimensies tussen die twee groepe aan die verskillende kultuurwaardes toegeskryf word. 'n Eienskap van die Egiptiese kultuur is die sterk kohesie en betrokkenheid in alle sosiale sfere, terwyl die Amerikaanse kultuur klem op kompetisie en individualisme plaas. Hiervan kan afgelei word dat die Egiptiese studente meer emosioneel tydens periodes van eensaamheid sal reageer en gevoelens van verlies sal ervaar, teenoor agitasie in die geval van die Amerikaanse studente (Ginter et al., 1995:528).

Rokach en Brock (1997:5) het ook ondersoek na die oorsake van eensaamheid ingestel. Hulle het Noord-Amerikaners, Suid-Asiese en Wes-Indiese respondente in hul studie ingesluit. Die laasgenoemde twee groepe was beduidend meer eensaam as die Noord-Amerikaners. Verder het die kulturele verskille tussen die groepe hul persepsies omtrent die oorsake van eensaamheid geaffekteer. Die Suid-Asiese groep het byvoorbeeld eensaamheid as gevoelens van minderwaardigheid en persoonlike ontoereikendheid beskou, terwyl die Noord-Amerikaners eensaamheid aan onbevredigende interpersoonlike verhoudings en die afwesigheid van sosiale ondersteuningsnetwerke toegeskryf het. Die Wes-Indiese groep was van opinie dat eensaamheid deur die skeiding van die individu van belangrike ondersteuningsisteme, veral die gesin, asook aanpassings by nuwe lewensomstandighede of onbekende kulture veroorsaak word (Rokach \& Brock, 1997:5).

Die mees resente Suid-Afrikaanse studie is deur Mullett (2002:102) uitgevoer waarin 453 adolessente (137 swart, 107 Kleurling en 209 wit) van Bloemfontein betrek is. Die gemiddelde ouderdom van die groep is 17,49 jaar. Eensaamheid is deur middel van die Le RouxEensaamheidsvraelys gemeet. Een van die belangrikste bevindings van die studie was dat beduidende verskille tussen die gemiddelde eensaamheidstellings van swart, Kleurling- en wit adolessente gevind is. Die swart en Kleurling-adolessente is beduidend meer eensaam as die wit adolessente, terwyl geen verskil tussen die gemiddelde eensaamheidstellings van swart en Kleurling-leerders gevind is nie.

In ' $\mathrm{n}$ ander resente ondersoek deur Le Roux en Connors (2001:48) het die navorsers 188 senior studente van die Charles Sturt University (CSU) in Nieu-Suid-Wallis en 104 Afrikaanssprekende senior studente van die Universiteit van die Vrystaat (UV) in Bloemfontein, Suid-Afrika, met mekaar vergelyk. Die resultate het eerstens getoon dat die twee groepe beduidend van mekaar verskil sover dit die ervaring van eensaamheid betref. Die studente van CSU was beduidend meer eensaam as die van die UV. Daar is ook gevind dat ouderdom geen invloed op gevoelens van eensaamheid uitgeoefen het nie, maar dat geslag wel ' $n$ invloed het. Die twee vroulike groepe verskil beduidend van mekaar. Die vroulike CSU-studente was beduidend meer eensaam as die UV se vroue-studente, terwyl geen verskille tussen die twee manlike groepe gevind kon word nie. ' $n$ Ander veranderlike wat ook ' $n$ beduidende resultaat opgelewer het, was sosio-ekonomiese status. Studente van die UV was beduidend minder eensaam as die van die CSU op twee vlakke van die veranderlike, naamlik die gemiddelde en die hoë sosio-ekonomiese groep. Die laaste bevinding van hierdie studie het interessante inligting opgelewer. Huislike omstandighede was in drie vlakke verdeel en die resultate het aangetoon dat die studente van die CSU wat in gelukkige ouerhuise opgegroei het, beduidend meer eensaam was as hul eweknieë in Suid-Afrika. Geen verskille tussen die groepe is op die ander twee vlakke van die onafhanklike veranderlike, naamlik nog gelukkig/nog ongelukkig en ongelukkig gevind nie.

Wat die studie van Groenewald (1998:91) betref, is 120 vroeë volwassenes ( 60 swart en 60 wit) by die ondersoek betrek. Die doel van die ondersoek was eerstens om te bepaal of daar ' $n$ verband tussen eensaamheid en sekere tipes sosiale gedrag bestaan. Sy wou ook vasstel of die groepe van mekaar verskil sover dit die verband betref. Die belangrikste bevinding van die studie was eerstens dat die graad van eensaamheid wat ervaar word, ' $n$ beduidende omgekeerde verband met die graad van sosiale gedrag of sosiale betrokkenheid toon. Geen verskil kon egter tussen die twee groepe gevind word sover dit die verband betref nie. Die studie het verder aangetoon dat hoe meer eensaam die jong manlike volwassenes is, hoe minder sosiaal aktief is hulle , en omgekeerd. In teenstelling hiermee is aangetoon dat die sosiale gedrag van die vroue geen effek op hul ervaring van eensaamheid gehad het nie. Laastens is ook bevind dat swart en wit ongetroude jong volwassenes van mekaar verskil sover dit eensaamheid betref. Die swart respondente was beduidend meer eensaam as die wit groep, wat korrespondeer met die bevindings van Peplau en Perlman (1982:11), wat aangetoon het dat swart volwassenes meer geneig tot eensaamheid as wit volwassenes is.

Pretorius (1993:47) van die Universiteit van die Wes-Kaap het in sy kruis-kulturele studie ondersoek ingestel na die psigometriese eienskappe van die Revised UCLA Loneliness Scale. Die resultate het getoon dat die Suid-Afrikaanse studente beduidend meer eensaam as Noord-Amerikaanse studente was, maar minder eensaam as Iranese en Puerto Rikaanse studente. Hierdie bevindinge is in ooreenstemming met die resultate van Jones, Carpenter en Quintana (1985:1508) wat 'n kruis-kulturele ondersoek tussen Amerikaanse en Puerto Rikaanse studente ingestel het. Die bevindings van hierdie projek verskil egter van die resultate van Wilson, Sibanda, Sibanda en Wilson (1988:577) wat geen verskille in eensaamheid onder swart en wit tienerseuns van Zimbabwe kon vind nie.

Wat eensaamheid en ouderdom betref, meen navorsers dat hoewel die term geneig is om gedagtes van ' $n$ bejaarde persoon wat geïsoleerd en alleen is, te ontlok, die ervaring 
daarvan deur die hele spektrum van menslike lewe aangetref en deur beide oud en jonk ervaar word (Demir \& Tarhan, 2(0)1:119; Nurmi et al., 1997:770). Hulle is ook van mening dat eensaamheid baie algemeen onder adolessente en jong volwassenes is, omdat verhoudings met die portuur een van die belangrikste ontwikkelingstake gedurende hierdie ouderdomsperiodes is. Faktore wat hierdie ontwikkelingsproses mag onderbreek, kan tot die ontstaan van verskeie vorme van eensaamheid lei (Demir \& Tarhan, 2001:119). Laasgenoemde navorsers beskou eensaamheid as een van die pynlikste en wydverspreide probleme onder adolessente (Demir \& Tarhan, 2001:119). Volgens hulle is eensaamheid dikwels die gevolg van gevoelens van isolasie en frustrasie oor ' $n$ behoefte om te behoort, en sulke gevoelens van sosiale eensaamheid mag uitgedruk word deur onttrekking, jeugmisdaad, mislukking op skool, en selfs selfmoord. Verder staan dit ook in verband met verskeie anti-sosiale gedragspatrone soos substansmisbruik, vandalisme, diefstal, en om van die huis af weg te loop, aldus Demir en Tarham (2001:119).

In die lig van die bogenoemde bespreking, is die hoofdoel van hierdie studie om te bepaal of studente van verskillende etniese afkoms van mekaar verskil wat hul ervaring van eensaamheid betref. Daar sal ook vasgestel word of geslag en ouderdom enige invloed op die ervaring van eensaamheid het en laastens wat die effek van hierdie veranderlikes op die konstruk is.

Die navorsinshipoteses is dus as volg:

- Swart en wit studente verskil van mekaar met betrekking tot hul ervaring van eensaamheid.

- Daar bestaan verskille ten opsigte van geslag en ouderdom sover dit eensaamheid betref.

\section{Metode \\ Die steekproef}

Die twee groepe wat in die ondersoek gebruik is, is as volg gevorm: 148 swart en 122 wit studente van die Fakulteit Geesteswetenskappe is by die ondersoek betrek. Van die totale groep van 270 was 109 manlik en 161 vroulik (sien Tabel 1). Die vraelyste is gedurende lesingtye onder studente gedistribueer en dit het hulle vrygestaan om aan die ondersoek deel te neem of nie.

\section{Die meetinstrumente}

Die Le Roux-Eensaamheidsvraelys asook " $n$ biografiese vraelys is in die ondersoek gebruik ten einde die nodige inligting te bekom. Die eersgenoemde vraelys is reeds in verskeie ondersoeke gebruik (Le Roux, 1992:5; Le Roux, 1998:176; Le Roux, 2001:92; Le Roux, 2002:324; Scholtz, 1995:61). Die vraeslys bestaan uit 30 items en die respondente moet aantoon in watter mate (of nie) hulle met elke stelling saamstem, deur die syfer in die kategorie van hul keuse te omsirkel. Die vier responskategorieë varieer van 'Altyd' tot 'Nooit'. Voorbeelde van die items in die vraelys is die volgende: "Ek het in " $\mathrm{n}$ liefdevolle ouerhuis opgegroei" (item 2); "Ek voel vergete (item 9); "My vriende maak my gelukkig" (item 24) en "Niemand kan my help nie' (item 28). Die skaal is ook gebalanseer, met 15 stellings wat negatief en 15 wat positief bewoord is. Die negatiewe items is gemerk met waardes wat wissel van 1 tot 4 in die verskillende responskategorieë, terwyl die positiewe items van 4 tot 1 varieer. Wat die interpretasie van die resultate betref, beteken ' $n$ lae telling dat die persoon nie tot eensaamheid geneig is nie, terwyl ' $n$ hoë telling die teenoorgestelde impliseer.

Die betroubaarheid van die vraelys is reeds by verskillende geleenthede ondersoek. In 'n studie deur Le Roux (1992:5) is dit op 0,88 vasgestel; deur Le Roux (2002:325) op 0,88; deur Le Roux (2001:94) op 0,91 en deur Scholtz (1995:63) op 0,87 . Wat die geldigheid van die vraelys betref, is " $n$ korrelasie van rpn $=-0,6116$ tussen die positiewe en negatiewe helftes van die skaal behaal (Le Roux, 1992:5).

Die biografiese vraelys bevat vrae rondom etnisiteit, geslag en ouderdom. Laasgenoemde is in twee vlakke verdeel, naamlik 15 tot 19 jaar en ouer as 20 jaar.

\section{Statistiese tegnieke}

Die hipoteses wat vir die ondersoek gestel is, is met behulp van ' $n$ faktoriale variansie-ontleding getoets. Die groot voordeel van hierdie tegniek is dat meer as een hipotese gelyktydig ondersoek kan word. 'n Ander voordeel is dat dit vasstel wat die gekombineerde invloed is wat die veranderlikes op mekaar uitoefen.

Die beduidendheidspeil vir die ondersoek word op $1 \%$ gestel.

\section{Resultate}

Die alfa-koëffisiënt vir die Le Roux-Eensaamheidsvraelys is weer eens in hierdie studie bereken en op 0,88 vasgestel. Dit vergelyk dus uitstekend met dié van vorige ondersoeke soos hierbo genoem.

In Tabel 1 word die gemiddeldes en standaardafwykings Tabel 1: Gemiddeldes en standaardafwykings van al
die veranderlikes

\begin{tabular}{|c|c|c|c|c|}
\hline \multicolumn{2}{|c|}{ Veranderlikes } & $\mathbf{N}$ & 8 & $s$ \\
\hline $\begin{array}{l}\text { Eensaamheid } \\
\text { · Etnies: }\end{array}$ & wit & $\begin{array}{l}122 \\
148\end{array}$ & $\begin{array}{l}47,631 \\
56,669\end{array}$ & $\begin{array}{l}10,274 \\
9,617\end{array}$ \\
\hline Geslag: & $\begin{array}{c}\text { manlik } \\
\text { vroulik }\end{array}$ & $\begin{array}{l}109 \\
161\end{array}$ & $\begin{array}{l}51,211 \\
53,516\end{array}$ & $\begin{array}{l}10,367 \\
11,146\end{array}$ \\
\hline Ouderdom & $\begin{array}{l}15-19 \\
20^{+}\end{array}$ & $\begin{array}{l}79 \\
191\end{array}$ & $\begin{array}{l}51,506 \\
53,031\end{array}$ & $\begin{array}{l}9,933 \\
11,240\end{array}$ \\
\hline
\end{tabular}




\section{Tabel 2: Faktoriale variansie-ontleding op al die veranderlikes met eensaamheid as afhanklike veranderlike en etnisiteit, geslag en ouderdom as onafhanklike veranderlikes}

\begin{tabular}{|c|c|c|c|c|}
\hline & vg & $\frac{\text { kwadraat }}{\mathrm{X}}$ & $\mathbf{F}$ & $\mathbf{p}$ \\
\hline $\begin{array}{l}\text { Hoofeffekte } \\
. \text { Geslag } \\
. \text { Ouderdom } \\
. \text { Etnies }\end{array}$ & $\begin{array}{l}1 \\
1 \\
1\end{array}$ & $\begin{array}{l}84,579 \\
419,277 \\
4989,991\end{array}$ & $\begin{array}{l}0,870 \\
4,314 \\
51,347\end{array}$ & $\begin{array}{l}0,352 \\
0,039^{*} \\
0,000^{* *}\end{array}$ \\
\hline $\begin{array}{l}\text { Tweerigting- interaksies } \\
\text {. Geslag/ouderdom } \\
\text {. Geslag/etnies } \\
\text {. Ouderdom/etnies }\end{array}$ & $\begin{array}{l}1 \\
1 \\
1\end{array}$ & $\begin{array}{l}7,273 \\
1,129 \\
53,317\end{array}$ & $\begin{array}{l}0,075 \\
0,012 \\
0,549\end{array}$ & $\begin{array}{l}0,785 \\
0,914 \\
0,460\end{array}$ \\
\hline $\begin{array}{l}\text { Drierigting- interaksies } \\
\text { - Geslag/Ouderdom/Etnies }\end{array}$ & 1 & 187,470 & 1,929 & 0,166 \\
\hline
\end{tabular}

dat die twee gemiddeldes in hierdie kategorie eenders is en nie van mekaar verskil nie. Studente in die ouderdomsgroep 20 jaar en ouer is nie meer eensaam as studente tussen 15-19 jaar nie.

Daarenteen toon Tabel 2 ook dat die F-waarde vir geslag onbeduidend is en geen effek op eensaamheid het nie. Die variansies rondom die gemiddeldes vir mans en vroue is eenders en veroorsaak nie verskille tussen die gemiddeldes vir mans en vroue nie.

Wat die interaksies betref, is die tweerigting-, sowel as die drierigtinginteraksies, onbeduidend.

van al die veranderlikes aangetref.

Die volgende afleidings kan vanuit die bogenoemde tabel gemaak word: Dit is eerstens duidelik dat 148 swart en 122 wit studente aan die ondersoek deelgeneem het. Van die 270 deelnemers was 109 manlik en 161 vroulik. Wat ouderdom betref, het 79 binne die kategorie 15-19 jaar geval, terwyl 191 studente 20 jaar en ouer was. Dit is verder ook duidelik dat die gemiddeldes van die twee etniese groepe (swart en wit) tot ' $\mathrm{n}$ redelike mate van mekaar verskil in vergelyking met die gemiddeldes vir geslag en ouderdom. Dit wil dus tentatief voorkom asof etnisiteit ' $n$ belangrike veranderlike by die voorkoms van eensaamheid is.

In hipotese 1 is gepostuleer dat swart en wit studente van mekaar verskil sover dit eensaamheid betref, asook dat geslag en ouderdom verskille ten opsigte van eensaamheid sal voortbring. Tabel 2 bevat die besonderhede van die faktoriale variansie-ontleding wat op al die veranderlikes uitgevoer is. Eensaamheid was die afhanklike veranderlike en etnisiteit, geslag en ouderdom die onafhanklike veranderlikes.

Volgens hierdie tabel blyk eerstens dat wat die hoofeffekte betref etnisiteit ' $n$ belangrike invloed op die afhanklike veranderlike, naamlik eensaamheid, uitoefen. Die F-waarde van 51,347 vir etnisiteit wat uit twee vlakke bestaan, naamlik wit en swart, is hoogs beduidend $(p \leq 0,000)$. Dit beteken dat nadat die variansies vir wit en swart ondersoek is, dit blyk dat die twee gemiddeldes nie eenders is nie, maar wel van mekaar verskil. Hiervolgens is swart studente beduidend meer eensaam as die wit groep.

Die F-waarde van 4,314 ten opsigte van ouderdom is onbeduidend wat impliseer dat nadat die variansies van die twee vlakke vir ouderdom ondersoek is, afgelei kan word
Dit beteken dat geeneen van die onafhanklike veranderlikes enige invloed op die vlakke van die ander onafhanklike veranderlikes uitoefen nie.

\section{Bespreking}

Die belangrikste bevinding van hierdie kruiskulturele ondersoek is dat kulturele agtergrond ' $n$ baie belangrike rol in die ondersoek na eensaamheid speel. Die hoofnavorsingshipotese waarin daar gepostuleer is dat swart en wit studente van mekaar verskil sover dit hul ervaring van eensaamheid betref, word dus hiermee bevestig. Volgens die resultate is swart studente beduidend meer eensaam as wit studente aan die Universiteit van die Vrystaat. Hierdie bevinding is in ooreenstemming met die resultate van ' $n$ hele aantal studies (Ginter et al., 1994:877; Groenewald, 1998:120; Mullett, 2002:129; Pretorius, 1993:105; Rokach \& Brock, 1997:10; Shumaker et al., 1993:69). Volgens hierdie navorsers word die Westerse kultuur gekenmerk deur individualisme en onafhanklikheid, met die gevolg dat hierdie kinders aan verskillende vlakke van outonomie blootgestel word. Dit kan dus wees dat swart studente wat meer tot ' $\mathrm{n}$ kollektivistiese kultuur behoort, dalk nie binne hul kulturele raamwerk die nodige vaardighede verkry of aangeleer het om verliese in hul sosiale ondersteuningsnetwerke alleen te kan hanteer nie. Dit kan ook wees dat die swart studente groter eensaamheid ervaar omdat hulle die slagoffers van industrialisasie, wat meer klem op individualisme plaas, geword het. As gevolg van die moontlike gebrek aan voldoende ondersteuning tydens die proses van anpassing by die nuwe omstandighede, asook die verlies aan belangrike ondersteuningsnetwerke, soos familie en vriende, word baie van hul basiese behoeftes soos interpersoonlike intimiteit en emosionele stabiliteit nie bevredig nie. Die resultaat is 
dan dat hulle meer en meer vereensaam.

Volgens McGraw (1992:319) se definisie vir eensaamheid moet hierdie toestand nie bloot as " $n$ gebrek aan intimiteit of betekenis gesien word nie, maar spesifiek as die soort van intimiteit wat betekenisvol is en in die vorm van betekenis wat intiem is. Hierdie siening korrespondeer ook met die opinies van verskeie ander skrywers, naamlik dat emosionele nood aan die wortel van eensaamheid gevind moet word (De Beer, 1992:127; Ferns, 1991:57; Peplau \& Perlman, 1982:15; Rokach \& Brock, 1997:3; Scholtz, 1995:32 $\&$ Weiss, 1973). Volgens hulle ontstaan emosionele eensaamheid deur óf die afwesigheid en/of die opheffing van emosionele bande binne sommige van die individu se verhoudings, ó deur omstandigheidsveranderinge binne hierdie verhoudings. Persone wat emosioneel geïsoleerd voel, het gewoonlik ' $n$ gebrek aan ' $n$ intieme verbondenheidsfiguur na wie hulle hulle in tye van krisis kan wend. Die verlatenheid en verwerping wat deur sulke individue ervaar word, lei dan tot gevoelens van leegheid en ' $n$ intense verlange na liefde en aanvaarding deur andere (Cruz, 1983:28).

Mullett (2002:125) is ook van opinie dat ' $n$ veranderlike soos sosio-ekonomiese status ' $n$ belangrike rol in swart en Kleurlingleerders se ervaring van eensaamheid kan speel. Volgens haar is armoede " $n$ ernstige probleem in Suid-Afrika en dit kan wees dat hierdie faktor ' $n$ belangrike rol in hierdie twee groepe se ervaring van eensaamheid speel. Sy is verder van mening dat die pandemiese afmetings van MIV/Vigs in Suid-Afrika ook nie geïgnoreer kan word nie. Ouersterftes, asook die besmetting van ongebore kinders wat later versorg moet word, veroorsaak 'n geweldige ekonomiese, emosionele en sosiale las op veral adolessente, terwyl hulle op ' $n$ baie kwesbare ontwikkelingstadium van hul lewens is. Sy gaan voort deur melding van die groot veranderinge die afgelope paar jaar in Suid-Afrika te maak. Hierdie veranderinge gaan met baie onrus en geweld gepaard, wat onteenseglik ook tot verskillende vlakke van eensaamheid kon bydra.

Daar is ook in hierdie studie gepostuleer dat daar verskille ten opsigte van geslag en ouderdom met betrekking tot eensaamheid bestaan. Hierdie hipoteses kon nie bevestig word nie, aangesien die F-waardes vir geslag en ouderdom albei onbeduidend is. Die tweerigting- sowel as die drierigting-interaksies is ook onbeduidend, wat aantoon dat geeneen van die onafhanklike veranderlikes enige invloed op die vlakke van die ander onafhanklike veranderlikes uitgeoefen het nie.

Die huidige ondersoek het ook " $n$ aantal tekortkominge wat in toekomstige studies aangespreek behoort te word. Eerstens kan die resultate nie as verteenwoordigend van die hele kampus se studente omtrent eensaamheid beskou word nie. Hoewel die Fakulteit Geesteswetenskappe een van die grootste fakulteite op die kampus van die Universiteit van die Vrystaat is, kan die bevindings ongelukkig nie as die algemene siening van die studente van die vyf ander fakulteite beskou word nie. " $n$ Volgende studie sal dus verteenwoordigend van die totale kampus se studente moet wees. Daar sal tweedens ook ondersoek ingestel moet word na die presiese aard van swart groepe se eensaamheid. Die meetinstrument moet miskien verder verfyn word sodat hierdie vraag beantwoord kan word, hoewel die betroubaarheid van die Le RouxEensaamheidskaal vir beide die groepe baie goed met mekaar vergelyk. Derdens is van toevallige steekproeftrekking gebruik gemaak, wat beteken dat alleen daardie studente wat tydens die ondersoek in die klasse teenwoordig was, deel van die ondersoekgroep uitgemaak het. Die navorser beveel aan dat daar van ewekansige steekproeftrekking by toekomstige ondersoeke gebruik gemaak sal word om vas te stel of soortgelyke resulte as die huidige gevind sal word.

\section{Gevolgtrekkings}

Die hoofbevinding van hierdie kruiskulturele navorsing is dat swart studente beduidend meer eensaam as wit studente van die Universiteit van die Vrystaat is. Dit beteken dat hulle volgens die bestaande literatuur, meer kwesbaar is ten opsigte van die ernstige gevolge wat eensaamheid vir hul fisiese en psigiese gesondheid inhou. Eensaamheid word onder andere geassosieer met fisiese probleme soos slaap- en eetversteurings, hoofpyn, chroniese moegheid en pyn, terwyl etlike sielkundige afwykings soos depressie, selfmoord, vyandigheid, jeugmisdaad, alkoholisme, homoseksualiteit, pessimisme en verwerping ook met hierdie fenomeen verbind word.

Geen samelewing kan dit bekostig dat sy jongmense wat in die toekoms die beheer moet oomeem, onder die negatiewe gevolge van hierdie fenomeen gebuk gaan nie. Eensaamhe:d het ten diepste met emosionele nood en 'n verlange na liefde en aanvaarding te doen, wat deur die afwesigheid en/ of opheffing van emosionele bande binne die individu se verhoudings of veranderings binne hierdie verhoudings veroorsaak word. Voeg hierby die armoedige omstandighede waarin baie swart jeugdiges opgroei, asook die geweldige ekonomiese, emosionele en sosiale las wat deur ouersterftes as gevolg van MIV/vigs veroorsaak word, die hoë egskeidingsyfer, kindermishandeling, seksuele molestering, misdaad, moord en verkragting en Suid-Afrika stuur af op ' $n$ ramp van onmeetlike omvang.

Dit is gebiedend noodsaaklik dat jongmense, veral swart adolessente, in hierdie tyd waarin samelewings al meer verval en agteruitgaan en mense meer en meer vereensaam, sal ervaar dat daar persone is wat vir hulle omgee en die lewe vir hulle meer draaglik kan maak. Persone in sekere beroepe soos gesondheid en onderwys, asook die verskillende kerklike denominasies is by uitstek geskik om hierdie rol te vervul. Die vraag is egter of hulle oor genoegsame arbeidskrag en die nodige infrastruktuur beskik om hierdie nuwe probleem die hoof te kan bied. Die Ministerie van Gesondheid, Onderwys en Welsyn sal hulle deeglik van hierdie nuwe dreigende gevaar moet vergewis.

\section{Bronnelys}

ALLPORT, G W \& ROSS, J M 1967: Personal religious orientation and prejudice. Journal of Personalitv and So- 
cial Psvchology. 5:432-443.

ANDERSSON, L 1993: Loneliness and its relationship with misery. Psychological Reports. 73:584-586.

BARRETTA, D DANTZLER, D \& KAYSON, W 1995: Factors related to loneliness. Psychological Reports. 76:827830.

BERG,S MELLSTRÖM, D PERSSON, G \& SVANBERG, A 1981: Loneliness in the Swedish Aged. Journal of Gerontology. 36:342-349.

CHEEK, J M BUSCH, C M 1981: The influence of shyness on loneliness in a new situation. Personality and Social Psychologv Bulletin. 7(4):72-577.

COUWENBERG, SW 1959: Die vereenzaming van de moderne mens. Gravenhage: N.V. Uitgeversmaatschappij Pax.

CRUZ, N 1983: Lonely, but never alone. Goodwood: Lux Verbi.

CUTRONA, CE 1982: Transition to college: Loneliness and the process of social adjustment. (In: LA Peplau \& D Perlman Eds. 1982: Loneliness: A sourcebook of theory, research, and therapy. New York: Wiley, pp 291-309).

DE BEER, E 1992: Eensaamheid en intimiteit by getroude studente in vroeë volwassenheid. Ongepubliseerde magisterverhandeling, Universiteit van die Vrystaat, Bloemfontein.

DEMIR, A, \& TARHAN, N 2001: Loneliness and social dissatisfaction in Turkish adolescents. The Journal of Psychology, 135(1):113-123.

DIAMANT, L \& WINDHOLZ, G 1981: Loneliness in college students: Some theoretical, empirical, and therapeutic considerations. Journal of College Student Personnel. 11:515-522.

FERNS, 1 1991: Determinante van vereensaming tydens vroeë volwassenheid. South African Journal of Psvchology, 21(1): 54-60.

GAEV, DM 1976: The psychologv of loneliness. Chicago: Adams.

GERSTEIN, LH \& TESSER, A 1987: Antecedents and responses associated with loneliness. Journal of Social and Personal Relationships. 4:39-363.

GINTER, EJ ABDEI-KHALEK, AM \& SCALISE,JJ 1995: Loneliness among young Egyptian Adults: Affective dimensions of loneliness. European Journal of Psvchological Assessment. 11(1):52-57.

GINTER, EJ GLAUSER, A \& RICHMOND, BO 1944: Loneliness, social support and anxiety among two South Pacific cultures. Psychological Reports. 74:875-879

GONZALEZ, JL 1997: Mother Theresa. London: Hodder \& Stoughton.

GROENEWALD, L 1998: 'n Kruiskulturele ondersoek na die verband tussen eensaamheid en sosiale gedrag. Ongepubliseerde magisterverhandeling, Universiteit van die Oranje-Vrystaat, Bloemfontein.

GRAHAM, B 1993: Noodberig. Cape Town: Struik Christelike Bocke Bpk.

HANSSON, RO \& JONES, WH 1981: Loneliness, cooperation and conformity among American undergraduates. The Journal of Social Psychology. 115:103-108.

HOJAT, M 1982: Loneliness as a function of selected personality variables. Journal of Clinical Psychology. 38(1):137141.

JANSE VAN RENSBURG, K 1991: Eensaamheid onder tieners in Oos-Londen. Ongepubliseerde magisterverhandeling, Universiteit van die Vrystaat, Bloemfontein.

JONES, WH CARPENTER, BN \& QUINTANA, D 1985: Personality and interpersonal predictors of loneliness in two cultures. Journal of Personality and Social Psvchology. 48:1503-1511

JONES, WH \& MOORE, TL 1987: Loneliness and social support. Journal of Social Behaviour and Personality. 2:145156.

JONES, WH SANSONE, C \& HELM, B 1983: Loneliness and interpersonal judgements. Personalitv and Social Psvchology Bulletin. 9(3):437-441.

KASTENBAUM, R 1979: Humans developing. A lifespan perspective. Boston: Allyn \& Bacon.

LE ROUX, A 1992: Loneliness in teenagers: A study of this phenomenon in Bloemfontein. Ongepubliseerde manuskrip, Bloemfontein.

LE ROUX, A 1996: Liefde. Die goue binddrade in ons verhoudings. Bloemfontein.

LE ROUX, A 1998. The relationship between loneliness and the Christian faith. South African Journal of Psvchology, 28(3), 174-181.

LE ROUX, A 2001. Die verband tussen die Christelike geloof en eensaamheid tydens laat-adolessensie. Acta Theologica. 21(1):83-105.

LE ROUX, A 2002: The Christian faith as predictor of loneliness. Scriptura. 79:320-335.

LE ROUX, A \& CONNORS, J 2001: A cross-cultural 
study into loneliness amongst university students. South African Journal of Psychology. 31(2):46-52.

LE ROUX, A \& DE BEER, E 1994: Eensalamheid en intimiteit onder getroude studente in vroeë volwassenheid. S.A. Joumal of Psvchology. 24(2):53-61.

LYNCH, JJ 1977: The broken heart. The medical consequences of loneliness. New York: Basic Books.

MACARTHUR, J 1995: Alone with God. Illinois: Victor Books.

MCGRAW, JG 1992: God and the problem of loneliness. Religious Studies. (28): 319-346.

MCWHIRTER, BT 1990: Factor Analysis of the Revised UCLA Loneliness Scale. Current Psvchologv: Research \& Reviews. 9(1):56-68.

MEDORA, N \& WOODWARD, JC 1986: Loneliness among adolescent college students at a midwestern university. Adolescence. 27(82):391-402.

MEDORA, N WOODWARD, JC \& LARSON, J 1987: Adolescent loneliness: A cross-cultural comparison of American and Asian Indians. International Journal of Comparative Sociology. 21(82):391-402.

MOORE, JA 1972: Loneliness: Personality, self-discrepancy and demographic variables. Dissertation Abstracts International. 34(5):2287B.

PRETORIUS, TB 1993: The metric equivalence of the Revised UCLA Loneliness Scale for a sample of South African Students. Educational and Psychological Measurement. 53: 232-236.

ROKACH, A 1988: Theoretical approaches to loneliness: From a univariate to a multi-dimensional experience. Review of Existential Psychology and Psvchiatry. 19(2\&3): 225-254.

ROKACH, A \& BROCK, H 1997: Loneliness: A multidimensional experience. Paper presented at the Ontario University, Canada.

ROKACH, A 2001: Criminal offense type and the causes of loneliness. The Journal of Psychology, 135(3):277-291.

RUBENSTEIN, CM \& SHAVER, P 1982: The experience of loneliness. (In Peplau LA \& Perlman. D Eds. 1982: Lonelincss: A sourcebook of current theory. research and therapv. New York: Wiley, pp 206-223.)

SCALISE, J J GINTER, E J \& GERSTEIN, LH 1984: A multi-dimensional loneliness measure: The Loneliness Rating Scale (LRS). Journal of Personality Assessment. 48 (5):525-530.

SCHOLTZ, E 1995: Eensaamheid onder Vista-studente in
Bloemfontein. Ongepubliseerde magisterverhandeling, Universiteit van die Oranje-Vrystaat, Bloemfontein.

WILSON, D SIBANDA, J SIBANDA, P \& WILSON, C 1989: Personality concomitants among black and white male Zimbabwean adolescents. The Journal of Social Psvchologv. 129: 577-578. 